JKEP

Vol 6, No 2 (2021)

ISSN: 2338-9095 (Print)

ISSN: 2338-9109 (online)

\title{
Model Pelatihan Blended Learning Meningkatkan Hasil Belajar Perawat Tentang Kamar Bedah Dasar
}

\author{
Pancaningsih \\ Badan Pemberdayaan Sumber Daya Manusia Provinsi DKI Jakarta \\ Email : pancaningsih21@gmail.com
}

Artikel history
Dikirim, Oct 10th, 2021
Ditinjau, Oct 31th, 2021
Diterima, Nop 27 th, 2021

\begin{abstract}
The world is facing pandemic situation of Covid-19, is a contagious and spread widely disease which caused high morbidity and mortality cases.The Virus spread very fast so we can not do any ofline teaching and learning activity. The need of learning process should be done by paying attention on effectivity and efficiency to reach the optimal result. The Blended Learning method becomes the solution for the need of learning process, especially for the nurse. The learning process was combined with online and offline way so the need of learning can be fulfilled in this pandemic situation. This research goals is to identifiy the Blended learning training effectivity to increase the result of the learning process in nursing about basic operating room. The research design is using pre experimental one group Pre Test and Post Test. The total respondents in this research is 50 nurses working in basic operating room in Dinas Kesehatan DKI Jakarta. This study used total sampling technique. This study was held in August September 2021 at Pusat pelatihan Central Java. The Training program was done for 4 days equal as 40 JPL (Online and Ofline). The Instrument used was Knowledge Questionaire developed by HIPKABI Jakarta. The Data analysis used was N Gain Score. The result showed there was an effective result in increasing learning process about basic operating room with the $N$ gain score $=71,812 \%$. The Blended Learning Method becames a consideration in process. We hope the lack in accessing internet can be minimized. The advantage that we can get was cost and time efficiency also the result of optimum learning process.
\end{abstract}

Key words : blended learning, learning result, basic operating room, training, nurse.

\begin{abstract}
ABSTRAK
Seluruh Dunia sedang dihadapkan dengan permasalahan pandemi Covid-19, dimana Covid-19 merupakan penyakit yang dapat menyebar dengan cepat dan sangat menular yang ditandai dengan meningkatkanya angka morbiditas dan mortalitas akibat Covid-19. Dengan penyebaran virus yang sangat cepat sehingga tidak memungkinkan melakukan pembelajaran dengan tatap muka, akan tetapi kebutuhan belajar harus tetap dilakukan dengan mempehatikan efektifitas dam efisiensi namun tetap mencapai luaran yang optimal. Metode pembelajaran blended learning menjadi solusi alternatif dalam menjawab kebutuhan belajar khususnya bagi perawat. Metode pembelajaran ini diharapkan mampu mengkombinasikan pembelajaran daring dan luring sehingga kebutuhan pembelajaran dapat terpenuhi dengan tetap mendukung kebijakan pemerintah dalam menekan peningkatan kasus baru terkonfirmasi posisitf Covid-19. Penelitian ini bertujuan untuk mengidentifikasi efektivitas metode pelatihan blended learning dalam meningkatkan hasil belajar perawat tentang kamar bedah dasar. Desain penelitian menggunakan pre eskperimen dengan one group pre-test and post-test. Sampel penelitian ini sebanyak 50 perawat kamar bedah di wilayah kerja Dinas Kesehatan Provinsi DKI Jakarta dengan
\end{abstract}


menggunakan teknik total sampling. Penelitian dilakukan pada bulan Agustus-September 2021 di Pusat Pelatihan Kesehatan Daerah Provinsi Jawa Tengah. Pelatihan dilakukan selama 4 hari sebanyak 40 JPL (daring dan luring). Instrumen penelitan menggunakan kuesioner pengetahuan yang dikembangkan HIPKABI Jakarta. Analisis data menggunakan N-Gain Score. Hasil penelitian menunjukkan terdapat pengaruh cukup efektif metode pelatihan blended learning dalam meningkatkan hasil belajar perawat tentang kamar bedah dasar dengan nilai $\mathrm{N}$-Gain $=$ $71,812 \%$. Metode pembelajaran ini menjadi pertimbangan dalam penyelenggaraan penelitian. Kekurangan dalam hal akses jaringan internet diharapkan dapat diminimalisir. Keuntungan yang didapatkan yaitu efisiensi biaya dan waktu serta luaran hasil belajar lebih optimal.

Kata kunci : blended learning, hasil belajar, kamar bedah, pelatihan, perawat

\section{PENDAHULUAN}

Tidak hanya Indonesia tetapi seluruh dunia saat ini sedang menghadapi masalah pandemi penyakit Corona Virus (Covid19). Virus ini pertama kali ditemukan di Wuhan, China pada Desember 2019. Virus ini bernama SARS -COV2 atau Corona Virus Disease 2019 (Covid-19).

Dengan adanya virus tersebut, maka ditemukan kasus pada tanggal 30 Juni 2020 , di Indonesia Covid-19 terdapat 56.385 kasus terkonfrimasi positif , 2.876 kasus meninggal dan 24.806 orang dinyatakan sembuh pada 34 Provinsi menurut Pusdatin Kemkes (2020), adapun jumlah kasus di Jakarta sebanyak 11.424, yaitu kasus positif 6.512 dinyatakan sembuh dan 640 lainnya meninggal dalam CNN Indonesia (2020), saat penanganan Covid-19, banyak perawat yang melayani pasien dengan kasus Covid-19 meninggal dengan jumlah 194 orang menurut PPNI dalam Tempo (2021). Tidak hanya Jakarta, tetapi juga negara-negara seperti Italia dan China melaporkan bahwa petugas kesehatan yang terkonfirmasi positif Covid-19 sekitar $20 \%$ dalam The Lancet (2020).

Menurut Peraturan Pemerintah N0 21 Tahun 2021, dengan adanya pandemi harus segera ditangani yaitu dengan melaksanakan Pembatasan Sosial Berskala Besar (PSBB) dan Percepatan Penanganan COVID-I9, sehingga kegiatan pembelajaran selama pandemi sebatas pembelajaran tatap muka sambil tetap melaksanakan protokol kesehatan dan pembelajaran jarak jauh. Salah satunya dengan menyelenggarakan kegiatan pelatihan yang merupakan kebutuhan untuk mendukung salah satu bentuk kegiatan peningkatan kompetensi serta tidak dapat dipisahkan (UU No 5, 2014), Sehingga pelaksanaan kegiatan pelatihan itu menjadi penting dan salah satu bentuk kegiatan peningkatan kapasitas sumber daya manusia saat pandemi ini adalah perawat yang bekerja yang terdapat di garda terdepan dalam melaksanakan tanggap darurat perlu mendapatkan informasi dan edukasi tentang keselamatan dan keamanan kerja (ILO 2020).

Salah satu pemberian infprmasi pada umumnya dengan memberikan Pendidikan dan pelatihan dengan tujuan pendidikan dan 
pelatihan adalah meningkatkan kemampuan kerja para pegawai dalam memberikan pelayanan terhadap masyarakat, terutama kesejahteraan umum dan mencerdaskan kehidupan masyarakat, serta kemampuan dalam bekerja seperti pengetahuan, sikap, kecakapan, dan keterampilan oleh Suwatno dan Priansa (2011). Pelaksanaan kegiatan pendidikan dan pelatihan di masa pandemi Covid-19 adalah mengubah metode belajaratau mpdel pembelajaran. Sesuai dengan Trianto (2015) yang dimaksud dengan model pembelajaran adalah membuat rencana atau desain yang dijadikan petunjuk untuk melakukan belajar dan mengajar di kelas atau pembelajaran secara tutorial. Diperlukan memilih model pembelajaran dengan tepat dan sesuai dengan perkembangan saat ini, diharapkan pembelajaran lebih efektif dan efisien guna meningkatkan kualitas. Begitu juga dengan ASN baik tenaga Pegawai Negeri Sipil (PNS) maupun Pegawai Pemerintah dengan Perjanjian Kerja (PPPK) berhak mendapatkan pengembangan kompetensi. Seperti halnya dengan aturan PP No 11 Tahun 2017 tentang Managemen Pegawai Negeri Sipil ditegaskan bahwa masing masing PNS mempunyai hak untuk mendapat pengembangan kemampuan selama 20 jam pelajaran (JP).

Salah satu dalam pemenuhan kebuthan akan kompetensinya adalah melakukan pelatihan dengan Metode Blended Learning merupakan pembelajaran yang merepresentasikan dijaman digital dimana sudah terintegrasi dengan jaringan internet. Blended Learning merupakan kegiatan pembelajaran yang mengabungkan penerapan pembelajaran tradisional di kelas dengan pembelajaran secara online yang memanfaatkan serta menggunakan teknologi informasi dan fleksibel oleh Ningsih, Masdalina, Marhamah 2017). Sistem pembelajaran dalam jaringan (online) adalah sistem pembelajaran yang dilakukan secara online tanpa bertemu langsung dan menggunakan teknologi internet.

Penelitian ini dengan menerapkan metode blended learning yaitu pembelajaran online dan juga tatap muka, dalam pengurangan jam pelajaran, digunakan untuk menyiasati dalam keberlangsungan pembelajaran tetap bisa efektif walaupun proses pembelajaran kebanyakan dengan menggunakan system online. Metode Blended Learning memiliki banyak keunggulan, di antaranya meningkatkan proses kontrol bagi siswa, mengurangi gangguan yang biasanya terjadi di kelas, menyederhanakan manajemen tugas, dan meningkatkan kinerja siswa menurut Borba at all dalam Husamah (2014). Blended learning adalah pembelajaran yang memadukan penyampaian pembelajaran dengan cara tatap muka dan pembelajaran dengan system pengunaan komputer secara 
offline maupun online (Dwiyogo, 2018). Blended learning adalah metode pembelajaran dengan saling bertemu yang didukung dengan pembelajaran menggunakan teknologi komputer (offline dan online) sehingga proses belajar mengajar berjalan dengan maksimal dan keduanya saling menlengkapi dalam metode tersebut dalam pembelajaran.

Salah satu kebutuhan pelatihan untuk melayani pasien Covid-19 di masa pandemi Covid-19 adalah melakukan operasi hingga membutuhkan pelatihan di ruang operasi atau di ruang operasi. Kamar operasi atau kamar Bedah adalah unit khusus di dalam rumah sakit yang berfungsi sebagai tempat pembedahan elektif atau akut yang memerlukan kondisi aseptik dan kondisi khusus lainnya (Kemenkes, 2012).

Proses pembelajaran dikatakan berhasil bila telah menunjukkan hasil yang sesuai dengan apa yang disampaikan (Simson dalam Huda, 2020). Untuk melihat proses tersebut diperlukan hasil belajar selama proses pelatihan dan begitu juga menurut Hamalik hasil belajar adalah adalah perubahan hasil belajar dari perilaku manusia yang dapat diamati dan diukur dalam bentuk pengetahuan. Pengetahuan merupakan hasil indera manusia atau hasil seseorang mengetahui tentang objek dari indera yang dimilikinya (Notoatmojo, 2012). Perubahan bisa sebagai arti meningkatnya dan berkembangnya kearah yang lebih baik dari yang sebelumnya yang diawali dari tidak tahu menjadi tahu. Dan hasil dari belajar adalah adalah hasil maksimal setelah mengikuti proses pembelajaran setelah mendapatkan materi tertentu didukung oleh Maisarah at all pada semua pembelajaran peserta dan hasil dari pembelajaran peserta, berada pada katagori tinggi, serta penilaian terhadap hasil pembelajaran mengalami peningkatan ,begitu juga menurut Sandy (2021) adalah hasil belajar kimia lebih tinggi pada siswa yang mengikuti Blended Learning.

Berdasarkan data di atas, dunia sedang mengalami pandemi Covid-19 dan sudah banyak yang terpapar bahkan meninggal dunia sehingga menyebabkan kegiatan perlu dibatasi dalam pelaksanaan kebutuhan pengembangan kompetensi serta kebutuhan informasi dan Pendidikan yang dibutuhkan. bagi masyarakat salah satunya perawat yang menjadi pemberi pelayanan terdepan dalam menangani Covid - 19 serta untuk menjaga keselamatan dan kesehatan kerja maka dilakukan pendidikan dan pelatihan untuk menjaga keselamatan kerja perawat salah satunya perawat kamar bedah dengan menggunakan pelatihan metode Blended learning dengan sesuai aturan protokol Kesehatan. 


\section{METODE}

Dalam penelitian ini menggunakan design pre eksperimen dengan jenis one group pre-test and post-test. Variabel independen yaitu metode pelatihan Blended Learning dan variabel dependen yaitu hasil belajar perawat tentang kamar bedah dasar. Adapun sampel pada penelitian ini seluruh peserta yang mengikuti pelatihan di Pusat Pelatihan Kesehatan Daerah (PUSLATKESDA) Dinas Kesehatan Provinsi DKI Jakarta dengan jumlah 50 peserta. Adapun Kriteria peserta adalah pada Rumah Sakit yang akan dibangun kamar bedah dan perawat dipersiapkan untuk menjadi rujukan pasien Covid-19 dengan indikasi pembedahan. Penelitian ini dilakukan pada bulan Agustus sampai September 2021 di Pusat Pelatihan Kesehatan Daerah Provinsi DKI Jakarta. Dengan sebelumnya melakukan ijin penelitian kepada Kepala Dinas Kesehatan Provinsi DKI Jakarta dengan nomor surat ijin adalah 9237/-1779.3. Instrumen penelitian menggunakan kuesioner pengetahuan berbentuk soal pilihan ganda sebanyak 40 pertanyaan di google form yang dikembangkan oleh Himpunan Perawat Kamar Bedah Indonesia (HIPKABI). Pelaksanaan dalam pengerjaan soal dilaksanakan pada tanggal
4 dan 8 November 2021 untuk Angkatan 1 serta 18 dan 22 November 2020 angkatan 2.

Pelatihan Perawat Kamar Bedah Dasar dilaksanakan selama empat hari (daring) dan dua hari (luring) di kamar bedah RS Yarsi Jakarta. Metode pelatihan berbentuk ceramah interaktif, diskusi tanya jawab, demonstrasi, dan simulasi.

Pelatihan dilakukan sebanyak 40 JPL terdiri dari 32 JPL daring dan 8 JPL luring. Peserta latih dibagi menjadi lima kelompok masing-masing kelompok dengan anggota lima orang perawat dan satu orang pelatih. Pelatih berasal dari anggota HIPKABI Provinsi DKI Jakarta. Peserta latih mendapatkan modul pelatihan, mengisi informed consent, pretest dan post-test. Analisis data univariat pada variabel usia, dan pengetahuan disajikan dalam mean dan standar deviasi. Variabel jenis kelamin, tingkat pendidikan, dan pengalaman kerja disajikan dalam frekuensi dan presentase. Analisis bivariat menggunakan uji $\mathrm{N}$-gain score. 


\section{HASIL DAN PEMBAHASAN}

Rerata usia peserta pelatihan kamar bedah dasar yaitu 31,2 tahun dengan $\mathrm{SD}=5,382$. Bersdasarkan rerata usia peserta pelatihan kamar bedah termasuk dalam klasifikasi Tabel 1. Karakteristik perawat kamar bedah berdasarkan usia $(n=50)$

Menurut Supriadi (2006) dan Suryani (2010) sebagian besar perawat yang bekerja di rumah sakit berusia sekitar 30 tahun, dan

Tabel 2. Karakteristik perawat kamar bedah berdasarkan jenis kelamin dan tingkat pendidikan dan pengalaman kerja $(\mathrm{n}=50)$

\begin{tabular}{lll}
\hline \multicolumn{1}{c}{ Variabel } & f & \% \\
\hline Jenis kelamin & & \\
Laki-laki & 30 & 60 \\
Perempuan & 20 & 40 \\
\hline
\end{tabular}

Sebagian besar perawat kamar bedah memiliki jenis kelamin laki-laki yaitu sebanyak $30(60 \%)$ perawat, Perawat kamar bedah sebagian besar laki-laki dimana salah satu tugas perawat kamar bedah adalah mentransfer pasien ke ruang pemulihan sehingga dibutuhkan tenaga yang kuat, dimana laki-laki memiliki kekuatan fisik yang lebih kuat dibandingkan dengan wanita dan mempunyai kekuatan otot atau tenaga yang kuat sehingga seseorang tetap dapat menyelesaikan kegiatannya dengan baik. Latar belakang pendidikan D3 Keperawatan yaitu sebanyak 34 (74\%). Dimana menurut dewasa awal dimana usia 26 - 35 tahun pada usia tersebut konsep dirinya sudah mandiri dan masuk dalam usia produktif. (Kemenkes, 2009).

\begin{tabular}{lccc}
\hline Variabel & Mean & SD & $\begin{array}{c}\text { Min- } \\
\text { Max }\end{array}$ \\
\hline Usia & 31,82 & 5,382 & $25-46$ \\
\hline
\end{tabular}

merupakan usia produktif yang membantu orang bekerja lebih baik dan berdedikasi, serta memiliki penilaian yang baik.

\begin{tabular}{lcc}
\hline Tingkat pendidikan & & \\
D3 & 37 & 74 \\
Ners & 13 & 26 \\
\hline Pengalaman kerja & & \\
< 3 tahun & 22 & 44 \\
$\geq 3$ tahun & 28 & 56 \\
\hline Jumlah & $\mathbf{5 0}$ & $\mathbf{1 0 0}$ \\
\hline
\end{tabular}

Rivai dan Mulyadi (2010), tingkat pendidikan seseorang mempengaruhi tingkat keterampilan yang ada. Dalam penelitiannya, Mulyaningsih (2013) menunjukkan bahwa perawat yang berpendidikan lebih baik menunjukkan pemikiran, kemampuan, dan keterampilan yang lebih sistematis dalam mencari pengetahuan baru dibandingkan dengan perawat yang dengan pendidikan kurang .Tingkat pendidikan yang tinggi mempengaruhi proses berpikir dan pengetahuan seseorang, Hasil dari pengalaman kerja dari peserta pelatihan, berjumlah 28 (56\%), menunjukkan 
pengalaman kerja lebih dari 3 tahun sehingga menurut Siagian (2008) menyatakan bahwa lamanya kerja menunjukan lama seseorang bekerja pada setiap pekerjaan atau jabatan serta menurut (Rivai \& Mulyadi, 2010) yaitu lama kerja seseorang akan menambah pengetahuan dan pengalaman, sehingga perawat yang bekerja lama akan lebih berpengalaman, menurut Handoko (2010)

Tabel 3. Gambaran Pengetahuan perawat tentang kamar bedah dasar sebelum dan setelah pelatihan $(n=50)$

Rerata pengetahuan sebelum pelatihan sebesar 51,46 dengan $\mathrm{SD}=18,975$ dan setelah pelatihan sebesar 92,54 dengan $\mathrm{SD}=$ 7,913. Pre test dan post test merupakan salah satu kegiatan evaluasi formatif yang berfungsi untuk tahu akan kemajuan dan perkembangan belajar seseoarang. Pre test adalah tes yang dilaksanakan diawal pembelajaran sedangkan post ttest adalah tes yang dilaksanakan setelah selesai pembelajaran. Majunya dan perkembangan

Tabel 4. Pengaruh metode pelatihan blended learning terhadap hasil belajar perawat tentang kamar bedah dasar

\begin{tabular}{ccccc} 
Variabel & $\begin{array}{c}\text { Mea } \\
\mathbf{n}\end{array}$ & SD & Min & $\begin{array}{c}\text { N- } \\
\text { Gain }\end{array}$ \\
\hline
\end{tabular}

menyatakan bahwa seseorang yang telah bekerja lebih dari 3 tahun termasuk dalam kategori lama.sehingga dapat disimpulkan bahwa perawat yag bekerja lebih dari 3 tahun akan mempunyai penambahan pengetahuan dan pengalamannya serta dengan tingkat pendidikannya bertambah juga ketarampilannya.

\begin{tabular}{lccc}
\hline \multicolumn{1}{c}{ Variabel } & Mean & SD & $\begin{array}{c}\text { Min- } \\
\text { Max }\end{array}$ \\
\hline Pengetahuan & & & \\
Pre-test & 51,46 & 18,975 & $23-98$ \\
Post-test & 92,54 & 7,913 & $73-$ \\
& & & 100 \\
\hline
\end{tabular}

belajar seseoramg dapat diketahui dengan memadukan keduanya. Demikian juga penelitian menurut Nursalam dan Suardi (2018), bahwa nilai total dari post test (setelah treatment) lebih tinggi dari pada pre test (sebelum treatment) yang diperoleh. Menurut Notoatmojo 2007, pengetahuan adalah kemampuan seseorang untuk mengungkapkan apa yang diketahui dengan bukti jawaban. lisan atau tertulis yang merupakan rangsangan dari pertanyaan.

\begin{tabular}{lcccc}
\hline & & & $\begin{array}{c}\text { Ma } \\
\mathbf{x}\end{array}$ & $\begin{array}{c}\text { Scor } \\
\mathbf{e}\end{array}$ \\
\hline Pengetahu & & & & \\
an & 51,4 & 18,97 & $23-$ & 71,81 \\
Pre-test & 6 & 5 & 98 & 2 \\
Post-test & 92,5 & 7,913 & $73-$ & \\
& 4 & & 100 & \\
\hline
\end{tabular}


Bahwa metode pelatihan blended learning cukup efektif dalam meningkatkan hasil belajar perawat tentang kamar bedah dasar dengan nilai $N$-Gain $=71,812 \%$. Hasil belajar untuk melihat sejauh mana peserta dapat paham akan materi dan metode pelatihan Blended Learning pada hasil belajar peserta pelatihan dasar ruang operasi selama pandemi Covid-19. Berbagai bentuk model pembelajaran dapat diterapkan berdasarkan kondisi dan kebutuhan, terutama

\section{SIMPULAN}

Metode pelatihan Blended Learning cukup efektif meningkatkan hasil belajar perawat tentang kamar bedah dasar. Metode pembelajaran Blended Learning menjadi alternatif pilihan dalam proses pelatihan perawat karena dapat meningkatkan pengetahuan dan keterampilan perawat tentang kamar bedah dasar khususnya selama masa pandemi Covid-19. Metode pembelajaran ini dapat diimplementasikan untuk peningkatan pengetahuan dan keterampilan lainnya. Adapun hasil penelitian ini diharapkan dapat menjadi data dasar dalam mengembangkan metode pembelajaran lain yang tepat diimplementasikan untuk meningkatkan pengetahuan, sikap, dan keterampilan secara optimal, efektif, dan efisien. di masa pandemi Covid-19. Sesuai dengan penelitian Mufidah, Surjanti (2021) bahwa keefektifan model Blended learning menunjukkan dapat peningkatan hasil belajar peserta yang ditunjukkan dengan nilai Sign (2-tailed). adalah 0,032<0,05. Begitu juga dengan (Fajar \& Riantika, 2019) yang mengungkapkan bahwa penerapan metode Blended Learning berhasil meningkatkan hasil belajar siswa secara signifikan

\section{SARAN}

Perlu adanya penelitian tentang efektivitas metode pembelajaran ini terhadap variabel lain seperti sikap, persepsi, motivasi, kesiapan, kepercayaan diri, keterampilan, dan perilaku perawat tentang kamar bedah dasar khususnya dan topik lainnya sesuai kebutuhan pada umumnya. Perlu dilakukan sinegitas dan kerjasama antara Puslatkesda DKI Jakarta dengan Badan Pengembangan Sumber Daya Manusia (BPSDM) DKI Jakarta untuk mecapai hasil yang lebih baik 


\section{UCAPAN TERIMA KASIH}

Peneliti mengucapkan terima kasih kepada seluruh pihak yang telah mendukung proses penelitian yaitu Badan Pembengan Sumber Daya Manusia (BPSDM) Provinsi DKI Jakarta, Dinas Kesehatan Provinsi DKI Jakarta, Pusat Pelatihan Kesehatan Daerah Provinsi DKI Jakarta, perawat kamar bedah, dan HIPKABI

\section{DAFTAR PUSTAKA}

Departemen Kesehatan RI. 2009. Kategori Usia. Dalam http://kategoriumurmenurut-Depkes.html.

Dwiyogo, Warsis D, 2018, Pembelajaran berbasis blended learning, Depok:PT Raja Grafindo Persada

Fajar, R., \& Riantika, P. (2019). Efektivitas Model Pembelajaran Blended Learning untuk Meningkatkan

Hasil Belajar Geografi pada Materi Litosfer Kelas X SMA. 2, 1723-1729. http://dx.doi.org/10.17977/jptpp.v4i1 2.13105

Handoko, T. Hani. (2010). Manajemen Personalia \& Sumber daya Manusia. BPFE-Yogyakarta

Huda (2013) Model-Model Pengajaran Dan Pembelajaran, hlm.167.)

Husamah. (2014). Pembelajaran Bauran Blended Learning) Terampil Memadukan

Keunggula

n

Pembelajaran Face-to-

Face, ELearning Offline-Online dan Mobil Learning. At-Turats, $9(2), \quad 75$.

https://doi.org/10.24260/atturats.v9i2.318

CNN Indonesia 30 Juni 2020, Update Corona https://www.cnnindonesia.com/nasio n al/20200630162228-20-

519119/update-corona-jakarta-

30- juni-11278-positif-6512sembuh

ILO, 2020, Dalam menghadapi pandemic : memastikan keselamatan dan kesehatan di tempat kerja https://www.ilo.org/wcmsp5/groups/p ublic/---asia/---ro-bangkok/---ilojakarta/documents/publication/wcms_ 742959.pdf

Kementrian Kesehatan RI. 2012, Pedoman Teknis Ruang Operasi, Jakarta:

Direktorat Bina PelayananPenunjang Medik dan Sarana Kesehatan Direktorat Bina Upaya Kesehatan

Mufidah, Surjanti (2021)

Efektivitas Model

Pembelajaran Blended

Learning dalam

Meningkatkan Kemandirian

dan Hasil Belajar

Peserta Didik pada Masa Pandemi

Covid-19

http://dx.doi.org/10.23887/ekuitas.v 9 i1.34186

Mulyaningsih. (2013), Peningkatan perilaku caring melalui kemampuan berpikir Kritis perawat. http://findarticles.com/p/articles/mi

Notoatmodjo, (2007). Ilmu Kesehatan Masyarakat. Jakarta: Rineka Cipta.

Notoatmodjo, 2012. Pendidikan dan perilaku kesehatan. Jakarta: Rineka Cipta

Sandi (2021) Pengaruh Blended Learning Terhadap Hasil Belajar Kimia Ditinjau Dari Kemandirian Siswa Jurnal Pendidikan Dan Pengajaran, Jilid 45, Nomor 3, Oktober 2012, Hlm.241-251

Ningsih , Misdalina , Marhamah (2017) Peningkatan Hasil Belajar dan Kemandirian Belajar Metode Statistika Melalui Pembelajaran 
Blended Learning, Al-Jabar: Jurnal Pendidikan Matematika Vol. 8, No. 2, 2017, Hal 155 - 164

Nursalam dan Suardi (2018) Perbandingan Pretest Dan Posttest Melalui

Peraturan Pemerintah Republik Indonesia Nomor 11 Tahun 2017 tentang Manajemen Pegawai Negri Sipil, Https://Jdihn.Go.Id/Files/4/2017pp011 .Pdf

Pradita, Rusita Ayu. 2016. Hubungan antara Jenis Kelamin dengan Hasil Belajar Siswa Kelas IV SD Negeri SeGugus I Kecamatan Sambit Kabupaten Ponorogo. Skripsi. Jurusan Kependidikan Sekolah Dasar dan Prasekolah. Universitas Negeri Malang. Pembimbing: (1) Dra. Sri Harmini, S.Pd. M.Pd., (2) Drs. Goenawan Roebyanto, M.Pd.

Pusdatin Kementerian Kesehatan https://Covid19.go.id/petasebaran Purwanto, Ngalim. 2012. Prinsip- Prinsip dan Teknik Evaluasi Pengajaran.Bandung: PT Remaja Rosdakarya.

Rivai, V \& Mulyadi, D. (2010), Kepemimpinan dan perilaku organisasi. Jakarta: PT Raja Grafindo Persada.Siagian, Sondang P. (2001). Manajemen Sumber Daya Manusia. Jakarta: Bumi Aksara
Penggunaan Media Power Point Vol.

2 No. 1 (2018): Produktif: Jurnal Ilmiah Pendidikan Teknologi Informasi

Siagian, Sondang P. (2001). Manajemen Sumber Daya Manusia. Jakarta: Bumi Aksara

Suwatno, DJ Priansa. 2011. "Manajemen SDM dalam organisasi Publik dan Bisnis". Bandung: Alfabeta. Alfabeta

Supriadi. (2008). Hubungan Karakteriktik Pekerjaan Dengan Pelaksanaan Perilaku Caring oleh Perawat Pelaksana di Ruang Rawat Inap Rumah Sakit Islam Samarinda. Tesis. FIK UI.

Suryani, (2010). Hubungan Lingkungan Kerja dengan Perilaku Caring Perawat di Rumah Sakit PGI Cikini Jakarta. Tesis. FIK UI.

Trianto (2015). Model Pembelajaran Terpadu. Jakarta: PT Bumi Aksara.

Tempo 2021, Detail data tenaga kesehatan yang meninggal karena covid -19 https://gaya.tempo.co/read/1487888/ d etail-data-tenaga-kesehatan-yangmeninggal-karena-Covid-19-sampaijuli-2021/full\&view=ok

Undang-Undang Republik Indonesia Nomor 5 Tahun 2014 Tentang Aparatur Sipil Negara 